\title{
Analisis Faktor yang Berpengaruh terhadap Ekspor Biodiesel di Uni Eropa
}

\author{
Aziz Pradana 1, Kusmantoro Edy Sularso ${ }^{2}$, Irene Kartika Eka Wijayanti ${ }^{2}$ \\ 1Program Studi Agribisnis Pascasarjana Universitas Jenderal Soedirman \\ 2Jurusan Sosial Ekonomi Pertanian Fakultas Pertanian, Universitas Jenderal Soedirman \\ E-mail: azizpradanaa@gmail.com
}

\begin{abstract}
Biodiesel is a substitute product for fossil oil or diesel which is made from vegetable oil. Indonesia as a producer of biodiesel which is made from palm oil. This derivative product of palm oil is supported by Government policies in its utilization and supply. This policy boosted the palm oil industry, so that production and export capacity increased for a decade. The European Union is the largest consumer of biodiesel. Therefore, Indonesia exports biodiesel to the European Union and has become one of the largest exporters in the region. The purpose of this study is to examine the factors that influence Indonesia's biodiesel exports in the European Union. The research method used is multiple linear regression analysis using OLS to examine the factors that affect the amount of Indonesian biodiesel exports in the European Union. The results show, the regression test of the factors that affect the amount of Indonesian biodiesel exports in the European Union, namely; EU biodiesel production and biodiesel consumption have a significant or positive effect on total exports of $0.54 \%$ and $0.14 \%$; the factor of the Rupiah exchange rate against the Euro, Indonesian biodiesel consumption, the dummy antidumping duty policy, international biodiesel prices and Indonesian diesel consumption have negative effects respectively $-0.04 \%,-0.63 \% ;-71.7 \% ;-0.27 \% ;-0.04$, while the CPO production factor and oil palm land area did not significantly affect the amount of biodiesel exports to the European Union. From these factors, the government needs to increase biodiesel production and maintain biodiesel consumption in the EU so that it does not decline. Increased bilateral diplomacy to partner countries in offering biodiesel needs to be increased so that Indonesian biodiesel has a very strong competitiveness and does not depend on just one trading partner.
\end{abstract}

Keywords: biodiesel, factors, regression, OLS.

\begin{abstract}
Abstrak
Biodiesel merupakan salah satu produk substitusi dari minyak fosil atau solar yang berbahan baku dari minyak nabati. Indonesia sebagai salah satu produsen biodiesel yang berbahan baku dari minyak kelapa sawit. Produk turunan produk minyak kelapa sawit ini didukung oleh kebijakan Pemerintah dalam pemanfaatan dan penyediaannya. Kebijakan tersebut mendorong industri minyak kelapa sawit, sehingga produksi dan kapasitas ekspor meningkat selama satu dekade. Uni Eropa merupakan konsumen terbesar biodiesel. Oleh sebab itu, Indonesia melakukan ekspor biodiesel ke wilayah Uni Eropa dan menjadi salah satu eksporti terbesar di wilayah tersebut. Tujuan penelitian ini yaitu mengkaji faktor - faktor yang berpengaruh terhadap ekspor biodiesel Indonesia di wilayah Uni Eropa. Metode penelitian yang digunakan adalah analisis regresi linier berganda menggunakan OLS untuk mengkaji faktor - faktor yang berpengaruh terhadap jumlah ekspor biodiesel Indonesia di wilayah Uni Eropa.Hasil penelitian menunjukan, uji regresi faktor - faktor yang berpengaruh terhadap jumlah ekspor biodiesel Indonesia di wilayah Uni Eropa yaitu; produksi biodiesel dan konsumsi biodiesel Uni Eropa berpengaruh nyata atau positif terhadap jumlah ekspor sebesar 0,54\% dan 0,14\%; faktor kurs Rupiah terhadap Euro, konsumsi biodiesel Indonesia, dummy kebijakan bea anti-dumping, harga biodiesel Internasional dan konsumsi solar Indonesia berpengaruh negatif masing - masing sebesar $-0,04 \% ;-0,63 \% ;-71,7 \% ;-0,27 \% ;-0,04$, sedangkan faktor produksi CPO dan luas lahan sawit tidak berpengaruh nyata terhadap jumlah ekspor biodiesel ke Uni Eropa. Dari faktor tersebut, pemerintah perlu meingkatkan produksi biodiesel dan menjaga konsumsi biodiesel di UE agar tidak mengalami penurunan. Peningkatan diplomasi bilateral ke negara - negara mitra dalam menawarkan biodiesel perlu ditingkatkan agar biodiesel Indonesia memiliki daya saing yang sangat kuat dan tidak tergantung pada salah satu mitra dagang saja.
\end{abstract}

Kata kunci: biodiesel, faktor, regresi, OLS. 


\section{Pendahul uan}

Minyak kelapa sawit atau CPO adalah komoditas utama ekspor Indonesia. Sebagai komoditas utama, jumlah produksi CPO yang dihasilkan 72\%nya diekspor masih dalam keadaan mentah dan 28\%nya digunakan sebagai produk turunan (Gapki, 2017). Produk turunan CPO dapat diolah menjadi industri pangan dan energi terbarukan. Salah satu turunan CPO yang sedang hangat dibahas dan diteliti adalah produk biodiesel sebagai energi terbarukan. Uni Eropa merupakan salah satu wilayah yang sudah lama memperhatikan lingkungan dalam pengeluaran emisi gas karbon dan menggunakan produk biodiesel. Menurut Andalia et.al (2018), biodiesel memiliki 7,9\% lebih rendah dari minyak solar dalam emisi gas buang karbon. Oleh sebab itu, tingkat produksi dan konsumsi biodiesel Uni Eropa terbesar di dunia yaitu sebesar 14,1 juta ton dan 19,75 juta ton (USDA 2019). Jumlah konsumsi yang lebih besar dari produksi sehingga Uni Eropa membutuhkan produk biodiesel tambahan dengan cara mengimpor ke negara - negara produsen biodiesel. Pada satu dekade ini, importir biodiesel di wilayah Uni Eropa terbesar adalah Indonesia dan Argentina.

Indonesia sebagai eksportir biodiesel terbesar di Uni Eropa memiliki peran yang strategis. Hal ini karena Indonesia memiliki sumber daya cukup melimpah. Produk biodiesel Indonesia didukung dengan melimpahnya sumber daya alam yaitu luas lahan dan jumlah CPO sebagai bahan baku biodiesel. Selain itu, pemerintah juga mendukung dalam menetapkan pemanfaatan dan penyediaan biodiesel.

Indonesia menjadi salah satu eksportir biodiesel terbesar di Uni Eropa, namun produk tersebut memiliki beberapa hambatan. Hambatan penetapan kebijakan bea anti-dumping dengan meningkatkan pajak impor yang tinggi oleh Uni Eropa pada tahun 2014 - 2016 sehingga jumlah ekspor biodiel Indonesia turun sangat signifikan (Dharmawan et.al 2018). Selain itu, adanya nilai pertukaran Rupiah terhadap Euro dan acuan harga biodiesel internasional dapat mempengaruhi jumlah yang diperdagangkan. Jumlah konsumsi biodiesel domestik tanpa diimbangi dengan produksi yang tinggi juga dapat menurunkan jumlah ekspor yang ditawarkan.

Meskipun adanya hambatan ekspor biodiesel Indonesia, namun terdapat dorongan agar ekspor tetap berjalan. Produksi biodiesel yang meningkat dengan sumber daya yang melimpah dapat mendorong jumlah penawaran ekspor biodiesel Indonesia ke Uni Eropa bahkan dunia. Tingginya tingkat konsumsi biodiesel Uni Eropa juga sebagai pendorong kegiatan ekspor biodiesel Indonesia.

Dari uraian di atas, untuk mengetahui lebih lanjut maka permasalahan yang dirumuskan yaitu faktor - faktor apa saja dan bagaimana faktor tersebut berpengaruh terhadap volume ekspor biodiesel Indonesia di wilayah Uni Eropa. Berdasarkan masalah yang telah diuraikan, maka tujuan penelitian ini yaitu untuk mengetahui dan mengkaji faktor - faktor yang berpengaruh terhadap volume ekspor biodiel Indonesia di Uni Eropa.

\section{Metode Penelitian}

Metode analisis yang digunakan yaitu analisis kuantitatif dan analisis kualitatif. Analisis kuantitatif dengan pengukuran faktor - faktor yang berpengaruh terhadap ekspor biodiesel Indonesia di wilayah Uni Eropa. Analisis yang digunakan yaitu uji regresi linear berganda dengan alat analisis OLS. Setelah dilakukan analisis kuantitatif 
tersebut, maka analisis kualitatif digunakan dengan mendeskripsikan hasil perhitungan yang didukung oleh literatur sebelumnya.

Penelitian dilakukan dengan menggunakan data sekunder yang dimulai tahun 2009 sampai tahun 2019 dan diambil pada setiap Kuartal atau setiap 3 bulan. Data yang digunakan merupakan data yang berkaitan dengan ekspor biodiesel Indonesia keUni Eropa.

Data yang digunakan dalam penelitian ini adalah time series selama 10 tahun yaitu dari Quartal I 2009 sampai Quartal IV 2019. Data tersebut merupakan jenis data sekunder yang diperoleh dari berbagai sumber.

Tabel 1. Jenis dan Sumber data

\begin{tabular}{|c|c|c|}
\hline No & Variabel & Sumber Data \\
\hline 1 & $\begin{array}{l}\text { Volume ekspor biodiesel } \\
\text { Indonesia ke UE }\end{array}$ & $\begin{array}{l}\text { Un-comtrade, } \\
\text { USDA, CEIC }\end{array}$ \\
\hline 2 & $\begin{array}{l}\text { Jumlah produksi } \\
\text { biodiesel }\end{array}$ & Aprobi \\
\hline 3 & Jumlah produksi CPO & BPS \\
\hline 4 & $\begin{array}{l}\text { Luas lahan sawit } \\
\text { Indonesia }\end{array}$ & BPS \\
\hline 5 & $\begin{array}{l}\text { Kurs Rupiah terhada } \\
\text { Euro }\end{array}$ & BI (Bank Ind) \\
\hline 6 & $\begin{array}{l}\text { Harga Biodiesel } \\
\text { Internasional }\end{array}$ & CEIC \\
\hline 7 & Konsumsi biodiesel UE & USDA \\
\hline 8 & $\begin{array}{l}\text { Konsumsi biodiesel } \\
\text { Indonesia }\end{array}$ & Aprobi \\
\hline 9 & $\begin{array}{l}\text { Konsumsi solar } \\
\text { Indonesia }\end{array}$ & BPH Migas \\
\hline
\end{tabular}

*sumber data diolah

Metode Ordinary Least Squares (OLS) digunakan untuk mengetahui adanya pengaruh variabel bebas terhadap variabel terikatnya. Tahapan metode Ordinary Least Squares (OLS) dalam analisis penelitian ini untuk mengetahui hubungan antara variabel terikat dan variabel bebas. Pada penelitian ini, untuk menguji apakah model yang digunakan memenuhi syarat goodness of fit sebagai parameter untuk mengetahui adanya suatu hubungan antara variabel bebas dan variabel terikat. Menurut Gujarati dan Porter
(2008), untuk mengetahui hubungan perlu diketahui nilai koefisien determinasi dalam regresi berganda yang dilambangkan tanda R2. Setelah itu, uji F dilakukan untuk mengetahui pengaruh semua variabel bebas secara simultan terhadap variabel terikat.

\section{Hasil dan Pembahasan}

\section{Gambaran Umum}

Uni Eropa merupakan salah satu wilayah yang mengkonsumsi biodiesel terbesar di dunia. Hal tersebut karena, masyarakat Uni Eropa lebih memperhatikan dampak lingkungan di masa depan. Menurut Andalia et. al (2018) bahan bakar biodiesel lebih baik dari solar karena memiliki 7,9 \% lebih rendah emisi gas yang dikeluarkan. Pada tahun 2019 jumlah produksi biodiesel Uni Eropa yang dihasilkan sebesar 14,1 juta ton, sedangkan jumlah konsumsi yang dibutuhkan sebesar 19,75 juta ton (USDA, 2019). Oleh karena itu, Uni Eropa mendatangkan produk biodiesel dari berbagai produsen luar untuk memenuhi kebutuhan konsumsi biodieselnya, salah satunya yaitu Indonesia.

Dalam satu dekade ini, Indonesia merupakan negara produsen biodiesel. Pertumbuhan produksi biodiesel dari tahun 2009 hingga tahun 2019 meningkat sangat signifikan, yaitu sebesar 239 ribu ton menjadi 7,74 juta ton biodiesel yang dihasilkan. Meningkatnya produksi biodiesel yang tinggi hal ini didukung oleh dukungan kebijakan pemerintah. Awal kebijakan tersebut dimulai melalui kebijakan Inpres RI No. 1 tahun 2006 dan Permen ESDM No. 051 tahun 2006. Selama kebijakan tersebut ditetapkan dan diperbaharui, industri biodiesel berjalan cukup optimal. Pencapaian jumlah produksi dan konsumsi biodiesel dalam negeri meningkat. Indonesia sebagai produsen biodiesel juga berperan sebagai eksportir biodiesel dunia. Dari jumlah 
biodiesel yang diperdagangkan, sebagian besar biodiesel diekspor ke wilayah Uni Eropa.

Selama satu dekade, ekspor biodiesel ke wilayah Uni Eropa mengalami kondisi yang sangat fluktuatif. Pada tahun 2009 hingga 2012 jumlah ekspor biodiesel Indonesia mengalami trend yang positif, yaitu meningkat dari 104,8 ribu ton tahun 2009 menjadi 1,1 juta ton di tahun 2012. Pada tahun 2013, ekspor biodiesel mulai menurun tajam hingga pada tahun 2016. Penurunan tersebut disebabkan karena penerbitan kebijakan dari wilayah Uni Eropa yaitu bea anti-dumping dengan menerapkan tarif pajak impor yang sangat tinggi. Uni Eropa menetapkan kebijakan tersebut pada tanggal 10 Juni 2014 atas tuduhan bahwa Indonesia melakukan dumping pada produk biodiesel kelapa sawit. Pada akhir 19 September 2016, melalui investigasi WTO bahwa Indonesia tidak terbukti melakukan kegiatan dumping pada produk ekspor biodieselnya (Gapki, 2017). Oleh sebab itu pada tahun 2017, ekspor biodiesel Indonesia di wilayah Uni Eropa kembali meningkat hingga pada tahun 2019.

Kebijakan bea anti-dumping oleh wilayah Uni Eropa pada produk biodiesel merupakan salah satu hambatan yang menurunkan jumlah ekspor biodiesel bagi Indonesia. Ada beberapa faktor penghambat maupun faktor penunjang untuk mendorong jumlah ekspor biodiesel ke wilayah Uni Eropa. Faktor tersebut dapat digambarkan secara umum sebagai variabel dependen yang diantaranya sebagai berikut :

a. Produksi Biodiesel

Perkembangan produksi biodiesel Indonesia dari Q1 2009 hingga Q4 2019 memiliki trend yang positif. Indonesia mendapatkan posisi ke 3 produsen biodiesel terbesar di dunia setelah Amerika Serikat karena produksi biodiesel hampir disetiap tahun meningkat (UFOP, 2019). Perkembangan ini terus meningkat karena dukungan penuh dari pemerintah, baik menteri ESDM (Energi Sumber Daya Mineral), menteri Pertanian hingga Presiden RI bapak Joko Widodo.

b. Produksi CPO

CPO atau minyak kelapa sawit merupakan salah satu bahan baku produk biodiesel. Indonesia merupakan produsen CPO terbesar di dunia hal ini karena didukung luas lahan kelapa sawit yang selalu meningkat. Produksi CPO memiliki tren positif atau dapat dikatakan setiap tahun produksi CPO meningkat dari Q1 2009 hingga Q4 2019. Meningkatnya produksi CPO tersebut, karena CPO merupakan salah satu komoditas utama dari Indonesia yang dapat menyumbang devisa negara sebesar kurang lebih 300 Triliun per tahun (Gapki, 2017). Peningkatan tersebut dapat didukung melalui perluasan lahan kebun kelapa sawit, peningkatan produktivitas, hilirisasi dan substitusi.

c. Luas Lahan Kelapa Sawit

Luas lahan kelapa sawit mengalami peningkatan dari tahun Q1 2009 hingga Q4 2019. Peningkatan tersebut karena meningkatnya jumlah permintaan CPO dalam negeri maupun dunia yang selalu meningkat. Jumlah permintaan CPO agar selalu terpenuhi, maka pemerintah berupaya melakukan per luasan lahan sawit demi meningkatkan produksi kelapa sawit selama beberapa dekade terakhir.

d. Nilai Tukar Rupiah terhadap Euro Nilai kurs Rupiah terhadap Euro selama 1 dekade dalam 4 kuartal mengalami beberapa fase yang fluktuatif. Nilai kurs Rupiah terhadap Euro selama 1 dekade 
cenderung di level Rp11.000 Rp17.000/ euro. Pada tahun 2009 selama 4 kuartal, rupiah mengalami penurunan terhadap Euro atau terapresiasi (penguatan) dari Rp15.000/euro hingga RP12.000/euro. Hal ini karena perumbuhan ekonomi meningkat dari nilai PDB tahun 2009 sebesar $4,63 \%$ menjadi $5,56 \%$ pada tahun 2013. Kemudian pada tahun 2013 Rupiah kembali terdepresiasi atau mengalami pelemahan oleh Euro hingga tahun 2016, hal ini karena pertumbuhan ekonomi Uni Eropa meningkat dari 0,05\% menjadi 2,05 \%. Pada tahun 2016 hingga 2019, Rupiah kembali terapresiasi atau mengalami penguatan karena PDB Indonesia meningkat pada tahun 2016 hingga 2018, sebesar 5,03\% menjadi $5,17 \%$, namun terjadi penurun di tahun 2019 menjadi 5,025. Pada tahun yang sama, PDB Uni Eropa terjadi penurunan dari 2,05 \% menjadi 1,53\%. Oleh sebab itu secara tahun 2016 hingga 2019 Rupiah mengalami penguatan terhadap Euro (World Bank, 2020). Hal ini sesuai dengan Suhendra (2003), bahwa pertumbuhan ekonomi dengan nilai PDB yang meningkat akan memperkuat nilai Rupiah dalam pertukaran mata uang dunia. Ramadhani (2015) menambahkan, bahwa penurunan pertumbuhan PDB dapat menyebabkan tingginya suku bunga dan inflasi sehingga dapat melemahkan nilai kurs rupiah atau terdepresiasi.

e. Harga Biodiesel Internasional Pada tahun 2009 harga biodiesel internasional cenderung menurun selama 4 kuartal, kemudian meningkat pada kuartal 2 tahun 2010 hingga kuartal 2 tahun 2011. Peningkatan tersebut karena meningkatnya permintaan biodiesel dunia dengan jumlah produksi biodiesel dunia yang lebih rendah (OECD-FAO, 2019). Pada kuartal 4 tahun 2014 hingga 2016 kuartal 1, harga biodiesel internasional mengalami penurunan yang signifikan, hal ini terjadi karena harga minyak mentah dunia juga mengalami penurunan yang cukup dalam (Kusuma, 2015). Pada kuartal 2 tahun 2016 harga biodiesel mulai kembali meningkat hingga kuartal 4 tahun 2019. Namun meningkatnya harga tersebut masih berada dibawah harga biodiesel pada tahun 2011 hingga 2014.

Menurut OECD-FAO (2019), kecendurungan harga biodiesel internasional berada di bawah 1.000 US\$/ton selama 4 tahun disebabkan melonjaknya produksi biodiesel di berbagai negara karena kebijakan standarisasi energi terbarukan. Melonjaknya produksi tersebut oleh negara - negara produsen biodiesel namun tidak didukung oleh permintaan negara - negara lain yang masih bergantung terhadap energi fosil. Pada umumnya negara tersebut adalah negara berkembang dan dibawahnya, karena masyarakat dan pemerintah yang belum mendukung adanya energi terbarukan (OECD-FAO, 2019).

f. Konsumsi Biodiesel Uni Eropa Uni Eropa merupakan wilayah negara negara maju, dengan tingkat kesadaran masyarakat akan energi terbarukan yang tinggi. Dari hal tersebut, masyarakat Uni Eropa lebih memilih bahan bakar nabati daripada bahan bakar fosil untuk digunakan sehari - hari. Oleh sebab itu, bahan bakar nabati biodiesel sangat dibutuhkan oleh Uni Eropa sehinggakonsumsi biodiesel di Uni Eropa meningkat dari kuartal 1 tahun 2009 hingga kuartal 4 tahun 2019 dapat dilihat dari Gambar 4.18. Pada tahun 2009 
hingga 2012 jumlah konsu msi biodiesel di Uni Eropa meningkat, sedangkan pada tahun 2013 mengalami penurunan hingga kuartal ke-4. Pada tahun 2014 hingga kuartal 3 tahun 2017 konsumsi UE cenderung stabil 4 juta ton biodiesel per kuartal. Padakuartal 4 tahun 2017 konsumsi UE kembali meningkat hingga kuartal 4 tahun 2019 mencapai 5,3 juta ton.

Kebijakan negara - negara Uni Eropa "Renewable Energy Road map" tentang pemanfaatan energi terbarukan sangat berpengaruh terhadap konsumsi biodiesel di Uni Eropa. Hal ini karena Uni Eropa menargetkan pada tahun 2020 pengurangan emisi gas karbon (CO2) sebesar 30\% (Amezaga et.al, 2010). Oleh sebab itu, pemerintah Uni Eropa dengan kesepakatan negara di wilayah Uni Eropa, menetapkan kewajiban transportasi menggunakan biodiesel untuk mensubstitusi bbm fosil / solar. Penetapan undang - undang tersebut meningkatkan jumlah permintan biodiesel, sehingga produksi biodiesel Uni Eropa dan jumlah impor biodiesel UE meningkat (USDA, 2019).

g. Konsumsi Biodiesel Indonesia (dalam negeri)

Dewasa ini, keadaan pemanasan global semakin meningkat, negara - negara maju dan berkembang berlomba - lomba dalam penggunaan energi terbarukan. Melalui kebijakan Inpres RI No. 1 tahun 2006 dan Permen ESDM No. 051 tahun 2006 tentang bahan bakar nabati atau energi terbarukan, konsumsi biodiesel Indonesia meningkat. Dewasa ini, keadaan pemanasan global semakin meningkat, negara - negara maju dan berkembang berlomba - lomba dalam penggunaan energi terbarukan. Melalui kebijakan Inpres RI No. 1 tahun 2006 dan
Permen ESDM No. 051 tahun 2006 tentang bahan bakar nabati atau energi terbarukan, konsumsi biodiesel Indonesia meningkat.

Pada kuartal 1 tahun 2009 hingga kuartal 4 tahun 2014, konsumsi biodiesel meningkat secara signifikan dari 22,8 ribu ton hingga 439,8 ribu ton. Namun pada tahun 2015, jumlah konsumsi biodiesel terkoreksi cukup dalam selama 4 kuartal penuh dan stagnan di level dengan jumlah konsumsi 180 - 283 ribu ton. Penurunan tersebut pada tahun 2015 disebabkan karena adanya penurunan harga minyak mentah dunia yang cukup dalam (Kusuma, 2015).

h. Konsumsi Solar Indonesia

Sejak tahun 2009 kuartal 1 hingga kuartal 4 konsumsi solar mengalami penurunan, yaitu dari 937 ribu ton solar turun menjadi 704 ribu ton. Pada tahun 2010 kuartal 1 konsumsi meningkat secara signifikan sebesar 2,9 juta ton. Hal ini karena adanya lonjakan peningkatan kendaraan bermotor baik, selain itu juga program penambahan panjang jalan tol yang dapat meningkatkan jumlah konsumsi solar. Menurut Muziansyah (2015), bahwa meningkatnya jumlah kendaraan bermotor yang signifikan mengakibatkan kebutuhan konsusm BBM semakin meningkat, khususnya pada bahan bakar solar dan bensin. Pada tahun 2010 hingga 2019, jumlah konsumsi solar di Indonesia berada di antara 2,5 juta ton hingga 3,5 juta ton solar yang dibutuhkan per tahun.

i. Dummy Kebijakan bea anti-dumping Biodiesel

Variabel dummy merupakan variabel yang bersifat kategorikal yang diduga mempunyai pengaruh terhadap variabel yang bersifat kontinue. Variabel dummy sering juga disebut variabel binary, 
kategorik atau dikotom. Variabel dummy hanya mempunyai 2 (dua) nilai yaitu 1 dan nilai 0 . Dummy memiliki nilai 1 $(D=1)$ untuk salah satu kategori dan nol $(D=0)$ untuk kategori yang lain. Nilai 0 biasanya menunjukkan kelompok yang tidak mendapat sebuah perlakuan dan 1 menunjukkan kelompok yang mendapat perlakuan (Kurniawan, 2015).

Variabel dummy digunakan pada kebijakan bea anti-dumping oleh Uni Eropa terhadap produk biodiesel Indonesia. Pada tanggal 10 Juni 2014 atau kuartal 2 tahun 2014 Uni Eropa menetapkan kebijakan tersebut dengan meningkatkan tarif pajak impor yang tinggi semula 2-5\% menjadi 8,8\% hingga 23,3\% per ton (Gapki, 2017). Hampir selama 3 tahun, Indonesia mengajukan gugatan kepada WTO atas tuduhan tersebut, dan WTO (World Trade Organization) menyatakan bahwa hasil penyelidikan Indonesia tidak melakukan praktik dumping produk biodiesel. Oleh sebab itu, WTO meminta UE untuk mencabut kebijakan bea anti-dumping terhadap biodiesel Indonesia. Pada tanggal 19 September 2016, atau kuartal ke 3 tahun 2016 UE mencabut kebijakan tersebut dan menerapkan pajak impor produk biodiesel Indonesia kembali normal. Berdasarkan kebijakan tersebut, maka selama kebijakan bea antidumping variabel dummy memiliki nilai $1(D=1)$, sedangkan sebelum adanya kebijakan dan setelah kebijakan tersebut dihapus maka variabel dummy memiliki nilai $0(\mathrm{D}=0)$.

Variasi atau naik turunnya jumlah ekspor biodiesel Indonesia di wilayah Uni Eropa dipengaruhi oleh produksi biodiesel, produksi CPO, luas lahan kelapa sawit, nilai tukar Rupiah terhadap Euro, harga biodiesel
Internasional, konsumsi biodiesel Uni Eropa, konsumsi biodiesel Indonesia (dalam negeri), konsumsi solar Indonesia, dan Dummy kebijakan bea anti-dumping oleh Uni Eropa dan sisanya 19,58\% dipengaruhi oleh faktor atau variabel lain di luar model. Secara simultan atau bersama - sama, faktor produksi biodiesel, produksi CPO, luas lahan kelapa sawit, nilai tukar Rupiah terhadap Euro, harga biodiesel internasional, konsumsi biodiesel Uni Eropa, konsumsi biodiesel Indonesia, konsumsi solar Indonesia dan dummy kebijakan bea anti-dumping oleh Uni Eropa berpengaruh nyata terhadap jumlah ekspor biodiesel Indonesia di wilayah Uni Eropa.

Variabel faktor produksi biodiesel berpengaruh nyata terhadap ekspor biodiesel di wilayah Uni Eropa. Hal tersebut karena ha diterima. Koefisien regresi pada variabel produksi biodiesel sebesar 0,5494 dan signifikan pada $\alpha 5 \%$. Hal ini menunjukkan bahwa setiap peningkatan produksi biodiesel sebesar $1 \%$ ekspor biodiesel Indonesia ke wilayah Uni Eropa meningkat sebesar 0,5494 \%. Peningkatan atau penurunan faktor produksi CPO (minyak mentah kelapa sawit) tidak berpengaruh nyata terhadap ekspor biodiesel Indonesia ke wilayah Uni Eropa. Setiap nilai rupiah mengalami penguatan (apresiasi) terhadap mata uang Euro, maka jumlah ekspor biodiesel ke Uni Eropa menurun. Dapat diartikan juga, setiap $1 \%$ nilai Rupiah mengalami penguatan terhadap mata uang Euro maka jumlah ekspor biodiesel ke Uni Eropa mengalami penurunan -0,0422\%.

Berdasarkan data yang diperoleh jumlah penawaran biodiesel berbanding lurus terhadap permintaan biodiesel di wilayah Uni Eropa. Oleh sebab itu, Indonesia melihat Uni Eropa merupakan mitra dagang yang memiliki peluang besar, sehingga produksi biodiesel juga perlu ditingkatkan. Menurut 
Dharmawan et.al (2018), bahw a peningkatan produksi biodiesel dapat meningkatkan kapasitas jumlah ekspor biodiesel. Namun menurut Purba dan Hartoyo (2010), peningkatan produksi biodiesel tidak berpengaruh nyata terhadap ekspor biodiesel Indonesia. Hal ini disebabkan karena pertumbuhan konsumsi dalam negeri yang tinggi sebesar $15,32 \%$, hal tersebut dapat menurunkan kapasitas ekspor yang ditawarkan. Pertumbuhan ekspor yang dilakukan hanya $0,17 \%$ dari jumlah produksi biodiesel yang dihasilkan.

Besaran luas lahan kelapa sawit yang meningkat atau menurun tidak berpengaruh terhadap meningkat atau menurunnya ekspor biodiesel Indonesia di wilayah Uni Eropa. Meskipun luas lahan kelapa sawit setiap tahun meningkat, namun peningkatan luas lahan tersebut tidak sebanding dengan peningkatan produksi dan ekspor biodiesel. Dari tahun 2009 hingga 2019, pertumbuhan luas kelapa sawit mencapai kurang lebih 17\% per tahun, sedangkan pada produksi dan ekspor biodiesel pertumbuhan mencapai 295\% dan 70\% per tahun. Oleh sebab itu, luas lahan tidak berpengaruh nyata terhadap ekspor biodiesel ke wilayah Uni Eropa. Tanpa perluasan lahan yang massive produktivitas CPO dan biodiesel dapat didukung dengan peramajaan dan penanaman varietas unggul kelapa sawit sebagai bahan dasar olahannya. Menurut Putra (2017), upaya percepatan dan pengembangan sektor perkebunan sawit dapat dilakukan melalui perluasan peremajaan. Melalui peramajaan tanaman kelapa sawit, produktivitas yang dihasilkan tetap dapat ditingkatkan dan lebih efisien.

Konsumsi solar Indonesia yang meningkat berpengaruh negatif terhadap jumlah ekspor biodiesel ke Uni Eropa. Oleh karena itu dari hasil nilai tersebut dapat diketahui, bahwa biodiesel merupakan salah satu produk substitusi dari produk bahan bakar minyak solar. Menurut Heyko (2013), untuk meningkatkan keamanan energi nasional dari ketergantungan energi fosil perlu adanya substitusi ke sumber energi terbarukan terlebih khusus pada bahan bakar nabati atau biodiesel. Hal ini disebabkan karena cadangan minyak Indonesia yang mengalami penurunan semenjak tahun 2001, sehingga berpotensi meningkatkan impor minyak bumi yang dapat meningkatkan biaya pengeluaran negara. Menurut Djumena (2019) bahwa, pelaksanaan penggunaan biodiesel merupakan solusi dalam mengurangi impor minyak mentah, pada tahun 2019 rata - rata impor solar bulanan turun 45 persen.

Faktor kebijakan bea anti-dumping merupakan faktor yang sangat merugikan bagi ekspor biodiesel Indonesia. Selama 3 tahun ditetapkannya kebijakan bea antidumping pada tahun 2014 hingga tahun 2016 ekspor biodiesel Indonesia ke wilayah Uni Eropa turun sangat dalam. Uni Eropa menetapkan kebijakan tersebut atas tuduhan kegiatan dumping oleh Indonesia terhadap produk biodiesel yang diperdagangkan. Dharmawan et.al (2018) menambahkan, alasan penetapan anti-dumping oleh UE bahwa harga biodiesel Indonesia dianggap melakukan penjualan yang lebih murah dari harga dunia, hal ini karena Indonesia memberikan subsidi pada produk biodiesel. Oleh sebab itu, UE menetapkan kebijakan bea anti dumping pada November 2013 hingga September 2016 dengan menerapkan tarif pajak impor yang tinggi. Berakhirnya kebijakan tersebut karena Organisasi Perdagangan Dunia/WTO mengabulkan gugatan Indonesia atas tuduhan Uni Eropa adalah tidak benar. 


\section{Simpulan}

Faktor - faktor yang dapat berpengaruh terhadap peningkatan ekspor biodiesel Indonesia di wilayah Uni Eropa adalah produksi biodiesel dan konsumsi biodiesel Uni Eropa. Faktor - faktor yang dapat menurunkan jumlah ekspor biodiesel Indonesia diantaranya yaitu nilai tukar Rupiah terhadap Euro, konsumsi biodiesel Indonesia dan kebijakan bea anti-dumping

\section{Daftar Pustaka}

Amezaga, J. M., Boyes, S. L., and Harrison, J. A. (2010). Biofuels Policy in the European Union. International Biofuels Converence. New Delhi.

Andalia, W., Sukarmansyah., dan A. Fauzie. (2018). Analisis Emisi Gas Buang Hasil Pembakaran Solar dan Biosolar (B25) pada Fire Tube Boiler. Journal POROS, Vol. 16 No.1 hal 86 - 93.

Dharmawan, A. H., Nuva., D.A. Sudaryanti., A. A. Prameswari., R. Amalia dan A. Dermawan. (2018). Pengembangan Bioenergi di Indonesia "Peluang dan Tantangan Kebijakan Industri Biodiesel". Working Paper 242, Pusat Penelitian Kehutanan Internasional (Cifor).

Djumena, A. (2019). Impor Solar Indonesia Turun 45 Persen. News. [on-line] https://medan.kompas.com/read/2019/ 08/13/050900126/impor-solarindonesia-turun-45-persen-ini-sebabnya. Diakses pada tgl 19 Oktober 2020.

FOP (UNION ZUR FÖRDERUNG VON OELUND PROTEIN PFLANZEN). (2019). UFOP Report on Global Market Supply 2019/2020. UFOP.de/files. Global Publication.

Gabungan Pengusaha Kelapa Sawit Indonesia [Gapki], (2017). Kemajuan Hilirisasi Minyak Sawit Indonesia. News. https://gapki.id/news/2476/kemajuan- oleh Uni Eropa, selain itu faktor harga biodiesel Internasional dan konsumsi solar Indonesia dapat berpengaruh dalam penurunan ekspor biodiesel di wilayah Uni Eropa jika taraf signifikansi dinaikkan menjadi 10\%. Faktor produksi CPO dan luas lahan tidak meningkatkan atau menurunkan jumlah ekspor biodiesel Indonesia di Uni Eropa.

hilirisasi-minyak-sawit-indonesia, [diakses tgl 16 Maret 2020].

Gabungan Pengusaha Kelapa Sawit Indonesia [Gapki], (2019). Kinerja Industri Sawit Indonesia 2019. Publikasi News. https://gapki.id/KINERJA_INDUSTRI_SA WIT_INDONESIA_2019.pdf [diakses tgl 100ktober 2020].

Ginting, A. M. (2013). Pengaruh Nilai Tukar Terhadap Ekspor Indonesia. Buletin Ilmiah Litbang Perdagangan, Vol.7 No.1, Hal 1 - 18. Pusat Pengkajian, Pengolahan Data dan Informasi (P3DI), Bidang Ekonomi dan Kebijakan Publik, Sekjen DPR RI. Jakarta.

Gujarati D.N., dan Porter D.C. (2008). Basic Econometrics 5th ed. New York (US): McGraw-Hill Companies, Inc.

Heyko, E. (2013). Strategi Pengembangan Energi Terbarukan Studi Pada Biodiesel, Bioethanol, Biomassa, dan Biogas di Indonesia. Jurnal Ilmiah Mahasiswa FEB Universitas Brawijaya Vol.2 (1). Universitas Brawijaya, Malang.

Kurniawan, I. (2015). Ekonometrika: Variabel Dummy. Modul Kuliah. MIPA, Unnes. Semarang.

Kusuma, D. R. (2015). Harga Minyak Dunia Merosot 68\% dalam 1,5 Tahun. News. [on-line]

https://finance.detik.com/energi/d3100444/harga-minyak-dunia-merosot- 
68-dalam-15-tahun di akses pada tanggal 10 Agustus 2020.

Muziansyah, D., R. Sulistyorini., dan S. Sebayang. (2015). Model Emisi Gas Buangan Kendaraan Bermotor Akibat Aktivitas Transportasi (Studi kasus: Terminal Pasar Bawah Ramayana Koita Bandar Lampung). JRSDD, Vol. 3 No. 1 hal 57 - 70. Bandar Lampung.

Nguyen, L., \& Zhang, L. (2020). Anatomy and Histology of Normal Liver and Spleen.In Diagnostic Pathology of Hematopoietic Disorders of Spleen and Liver (pp. 1-9). Springer, Cham.

Nuva., A. Fauzi., A. H. Dharmawan., dan E. I. K. Putri. (2019). Ekonomi Politik Energi Terbarukan dan Pengembangan Wilayah: Persoalan Pengembangan Biodiesel di Indonesia. Sodality: Jurnal Sosiologi Pedesaan Vol. 7 No. 2 hal 110 - 118. Institut Pertanian Bogor. Bogor.

OECD-FAO (Organisation for Economic CoOperation Development - Food and Agriculture Organization. (2019). Agricultural Outlook. Publications outlook. www.agri-outlook.org [On-line]. diakses tanggal 2 September 2020.

Purba, J. H. V., dan S. Hartoyo. (2010). Dampak Kenaikan Harga Minyak Bumi Terhadap Permintaan CPO untuk Biodiesel dan Beberapa Aspek pada Industri Kelapa Sawit Indonesia. Jurnal Ilmiah Manajemen dan Akuntansi Fakultas Ekonomi (JIMAFE), Vol Semeseter. 1. Hal 37 - 49. Pascasarjana IPB. Bogor.

Putra, B. A. (2017). Partisipasi Petani Plasma Dalam Kegiatan Peremajaan Kelapa Sawit Eks Pola PIR BUN Di Koperasi Perkebunan Sawit Perintis PIR BUN
OPHIR Pasaman Barat. Skripsi. Fakultas Pertanian, Universitas Andalas. Padang.

Ramadhani, S. A. (2015). Pengaruh Produk Domestik Bruto, Inflasi dan Capital Account terhadap Nilai Tukar Rupiah Atas Dollar Amerika Serikat Periode tahun 2001 - 2014. Jom FEKON Vol.2. No. 2. Pekanbaru, Riau.

Sadewo, H. (2012). Analisis Kebijakan Mandatory Pemanfaatan Biodiesel di Indonesia. Tesis. Magister Perencanaan dan Kebijakan Publik. Fakultas Ekonomi. Universitas Indonesia. Jakarta.

Suhendra, I. (2003). Pengaruh Faktor Fundamental, Faktor Resiko, dan Ekspektasi Nilai Tukar terhadap Nilai Tukar Rupiah ( Terhadap Dollar) Pasca Penerapan Kurs Mengambang Bebas Pada Tanggal 14 Agustus 1997 (Periode September 1997 S.D. Desember 2001). Buletin Ekonomi Moneter dan Perbankan, Volume 3 No. 5, hal. 24-34.

USDA (United States Department of Agriculture). (2019). Gain Report: EU Biofuels Annual 2019. GAIN Report Number:NL9022. apps.fas.usda.gov.

Widyaningtyas, D. dan T. Widodo. (2016). Analisis Pangsa Pasar dan Daya Saing CPO Indonesia di Uni Eropa. Jurnal Ekonomi Manajamen Sumber Daya Vol. 18, No.2, hal $138-145$.

World Bank. (2020). GDP Growth (Annual \%) - Indonesia.World Bank national accounts data, and OECD National Accounts data files. https://data.worldbank.org/indicator/N Y.GDP.MKTP.KD.ZG?end=2019\&locations =ID\&start=2004[On-line] diakses pada tanggal 23 September 2020. 